\title{
The Pestalozzi Method: Mathematics as a Way to the Truth
}

\author{
Peri Mesquida, Fabio Inácio Pereira, Maurício Eduardo Bernz \\ Pontifical Catholic University of Paraná (PUCPR), Curitiba, Brazil \\ Email: mesquida.peri@gmail.com, fabio.inacio@pucpr.br, mauricio.bernz@colegiosmaristas.com.br
}

How to cite this paper: Mesquida, P., Pereira, F. I., \& Bernz, M. E. (2017). The Pestalozzi Method: Mathematics as a Way to the Truth. Creative Education, 8, 10881098.

https://doi.org/10.4236/ce.2017.87078

Received: April 20, 2017

Accepted: June 16, 2017

Published: June 19, 2017

Copyright (c) 2017 by authors and Scientific Research Publishing Inc. This work is licensed under the Creative Commons Attribution International License (CC BY 4.0).

http://creativecommons.org/licenses/by/4.0/ (c) (i) Open Access

\begin{abstract}
Johann Heinrich Pestalozzi (1746-1827), the father of modern pedagogy (Soëtard, 1985), dedicated his life to the pursuit of truth for mankind. This quest considered the education and teaching of children as a whole hence, his famous formula of "head, heart, and hands" was conceived not just as a slogan but, particularly, as a concept of comprehensive education. But how do you get to the truth behind education and teaching? How do you teach and educate children? What method ought to be used for this task? Pestalozzi wrote five volumes on his own Method (in Germany), which were later translated into French, and in these, he aimed to address the three questions mentioned above. Ever since the first attempt to explain the Pestalozzi Method, by Marc Antoine JULLIEN in his work Spirit of the Method of Pestalozzi education (Esprit de la Méthode d'Éducation de Pestalozzi) (1812), followed by Daniel Alexandre CHAVANNES in his Elemental Method of H. Pestalozzi (Méthode Élémentaire de H. Pestalozzi) (1819) and the works of Soëtard (1994) and Thröler (2008), many of the Method's concepts have been discussed and defended. However, the various authors do not appear to have settled on a common ground. Nevertheless, this article aims to offer a reflection on the subject based on a reading and analysis of the texts by Pestalozzi that were translated into French. It will attempt to defend the argument that Pestalozzi appropriated the inductive Method of Locke and Comenios who, like himself, were protestants, and whose methodological resources for finding the "Truth" through both education and teaching involved geometry and mathematics; these were elements that Pestalozzi considered useful for approaching and identifying truth and accuracy.
\end{abstract}

\section{Keywords}

Pestalozzi Methods, Children's Education, Geometry, Mathematics, Truth

\section{Introduction}

Pestalozzi: An overview of his life 
Johann Heinrich Pestalozzi was born in Zurich, Switzerland, on January 12, 1746, in a middle-class family; his father was a doctor and his mother was a housewife. In his youth, Pestalozzi became involved in politics, and his attempts to expose the abuses and corruption committed by officials led to his imprisonment. His militancy and political views led him to write about the topic in a work that reflects on the French revolution (Pestalozzi, 2007). However, politics would also appear in other works by Pestalozzi, such as To the innocence, the gravity and the nobility of my time and my country ( $\dot{A}$ l'Innocence, à la gravité et à la noblesse de mon époque et de ma patrie) (Lausanne: LEP Éditions Loisirs et Pédagogie SA, 2012). The importance he accorded to politics (not partisan politics but the politics considered by Aristotle), and its relationship with education, as well as the relationship between education and politics can be discerned in the following statement: "The beginning and end of my politics is education" (Pestalozzi, 2012: p. 34). ${ }^{1}$ Pestalozzi spent the final years of his life in Yverdon-Les-Bains, in "exile" from his home in the Canton of Zurich. He died in 1827.

The Swiss pedagogue took every step possible to convince the government to adopt his educational Method and to have it implemented in public schools throughout the Swiss Confederation. As such, he requested that the Swiss authorities give him their opinions regarding the content and practice of his $\mathrm{Me}$ thod and its feasibility at the national level. His Method was assessed on three occasions: in July 1802 (Report Ith), in March 1806 (Rapport Chavannes), and in May 1810 (Rapport Girard); however, Pestalozzi, despite being praised by the evaluators for his Method, never saw it adopted or made universal by the government, that is, by the Swiss Confederation. In fact, even he did not believe that his Method was finished and ready for universal application; rather, to him, the Method needed to be reworked on a case-by-case basis: "I have been seeking for quite some time now a world to simply yet accurately express what my Method in fact is. I have never found it, neither before nor after. The reason for this is clear: my Method is not yet complete" (Pestalozzi, 2008: p. 18). ${ }^{2}$

\section{Pestalozzi: Head, Heart, and Hand (Kopf, Herz, Hand)}

All of Pestalozzi's educational work is based and performed on this trio. It is no accident that heart is placed at the center of the trio. It feeds and fulfills the wholeness of human beings: their minds, feelings, and actions or, even, their intellect, feelings, and actions. In the present day, it could be translated into the formulation of knowing how to think, feel, and act, as knowing how to think is nourished by feeling, just like the dynamic source of knowing how to act is the heart. Strictly speaking, if the emphasis is placed on the heart, it is because Pestalozzi's pedagogy is a pedagogy of love. In the first volume of Writings on the Method (Écrits sur la Méthode), Pestalozzi defends what we would call the 
anthropology of love. Love, in the articulation of moral education, religious education, and teaching/learning, makes the act of educating a practice in which the interrelated elements of trust, justice, respect, and affection express themselves, making the practice of pedagogy a vocation that is dynamic and joyful (as Snyders (1988) writes in Joy in School. São Paulo: Ed. Manole, 1988). The central role played by the pedagogy of love in Pestalozzi's educational thought led him to observe that "elementary education aims at educating, through the use of its own means and by virtue of its harmony, the mind, heart, and hands towards performing to the best of our abilities" (Pestalozzi, 2008: p. 99). ${ }^{3}$ It is important to stress the fact that by emphasizing the "heart," feeling, and love as points of reference in the practice of childhood education, which in turn illuminates intellectual and "artistic, aesthetic, and professional" training, Pestalozzi highlights that the results of this loving relationship are trust, respect, and justice, which are fundamental in the relationship between the educator and the educated. Therefore, Pestalozzi asserts that "an intellectual training that is accompanied by the education of the heart can bear nothing other than the fruit of love" (Pestalozzi, 2008: p. 89). ${ }^{4}$

In her Letter from Stans (Lettre de Stans), (1985), Pestalozzi says that as long as "man" and, by extension, the educator, wishes "well" and demonstrates this to the child, the child will in turn:

Listen carefully; but, the child does not do this for you, master, nor because of you, educator, the child does so for himself/herself. The goodness that you want the child to achieve must not be the result of a whim of yours, or of your passion...this goodness must be good in itself because of the nature of the goodness itself, and must appear this way in the child's eyes (Pestalozzi, 1985: p. 25). ${ }^{5}$

Ultimately, to create this goodness, it is necessary that the educator desires that the child feels and follows the example he has set. This is not a discourse on goodness, but rather an unequivocal demonstration that educators are good, mean well, and love both their own profession and the child.

It is to this end that the meaning of the Latin verb educare can be understood. Etymologically, it means education that starts at the cuore, the heart, and which is expressed as love. Nevertheless, it is worth remembering that Pestalozzi's idea of love is closely related to consciousness, which in turn is related to human beings' rational ability inherent in their own nature, a fact that eliminates both soppiness and sentimentalism. With this in mind, autonomy, freedom, and the ability to maintain a dialogue might also be a part of this construct.

${ }^{3} \mathrm{La}$ formation élémentaire ne se proporse pas moins que d'élever, à travers chacun des moyens qu'elle utilize et grace à leur harmonie, le coeur, l'esprit et la main vers le meilleur de ce dont notre nature est capable.

${ }^{4}$ Une formation intellectuelle qui ne vient pas accompagnée d'une formation du coeur, ne peut pas produire les fruits de l'amour.

${ }^{5}$ Lui prête si volontiers une orielle attentive; mais il ne veut pas pour toi, maître, il ne veut pas pour toi, éducateur, il le veut pour il même. Le bien auuel tu veux le faire accéder ne doit pas être le fruit dun caprice de ton humeur ou de la passion...il doit être bon en soi, conformément à la nature de la chose, il doit apparaître comme bon aux yeux de l'enfant. 


\section{Plutarch's Water Pail, and Pestalozzi's Vase}

However, this perspective on education is not originally Pestalozzi's. Plutarch (45-120), also known as Lucius Mestrius PLUTARCHIUS, had already come to this conclusion 1.700 years before the Swiss pedagogue. Plutarch's work, titled in English on the education of children (In French: Sur l'éducation des enfants) (Plutarch, 1927, Moralia, Volume 1. Cambridge, MA:Loeb Classical Library, Harvard University Press), includes the following idea:

"The mind does not require to be filled like a bottle, but rather, like wood, it only requires kindling to create in it an impulse to think independently and an ardent desire for the truth."

By providing us modern educators with this sentence, at a time when we are concerned about merely infusing students with knowledge without considering that they need "kindling" to spur their abilities and to encourage them to continue seeking the truth, Plutarch has clearly summarized what educating means.

\section{Pestalozzi and His Method}

Strictly speaking, what Pestalozzi calls "My Method" (always with a capital "M") concerns not only the use of teaching techniques or didactic-pedagogic instruments but, rather, the combination of pedagogic theory and practice, including philosophy, psychology, and education policy. From his very first pedagogic experiences with poor children in Neuhof and later in Stans, Pestalozzi sought to unite practice and theory. Authors differ as to the meaning of the Method, or as some say, "the spirit of the Method" (Soëtard, 1982). However, it is clear, either through the Swiss educator's writings or especially in the expert reports that were produced upon Pestalozzi's request by educational institutions, that Pestalozzi's Method is a set of educational actions designed to be performed in schools as well as in the institutes he established. These educational actions involve teaching not only techniques and didactic-pedagogic resources, but also pragmatic content and, in particular, effecting a teacher-student relationship based on respect through dialogue, freedom, and what he calls "Moral.". It ranges progressively from concrete to the abstract, from the sensitive to the resilient, and from theory to experience: "This Method aims to develop as many of the children's intellectual abilities as possible, keeping pace with nature" (Pestalozzi, 2011: p. 126). ${ }^{7}$

The Method progressively proceeds through "gradation from the simple to the complex" (Pestalozzi, 2013: p. 84), leading the child to uncover the reality expressed by words. This is a development of education according to the children's ages (“development of education according to the children's ages") (Pestalozzi, 2009: p. 178 and 2013: p. 19).

${ }^{6}$ L'esprit n'est pas comme un jarre qu'il ne faille que remplir. Semblable aux matières combustibles, il a plutôt besoin d'un aliment qui l'échauffe, qui donne l'essor à ses facultés et l'enflamme pour la recherche de la vérité.

${ }^{7}$ Cette Méthode a pour but de chercher à donner à plus grand développement possible aus facultés intellectuelles des enfants, et cela, en suivant la marche de la nature. 
With this in mind, the free and independent man and education play a fundamental role in helping human beings forge themselves.

However, the Method, as we have seen above, is not, in essence, a group of techniques or didactic instruments, but rather a set consisting of techniques, didactic means, pedagogic action, content, and practice. Moreover, Pestalozzi's Method must be developed by the mature initiative of each pupil.

Therefore, he recommends that every educational institution organize itself in a suitable fashion in all branches of education, so that "every lesson can be tailored to the willingness and needs of the child."

The induction takes the opposite course by leading thought and action from the specific towards the universal, the sensitive to the resilient, from the empirical to the abstract, from practice to theory. This sub-chapter seeks to discern the theoretical-practical elements of what we call "method" in Pestalozzi's Methods, as well as the didactic-pedagogic means that he requires, temporarily setting aside the specific elements that constitute the method.

Pestalozzi says that "from the intellectual point of view, the idea of elementary education maintains the pedagogical principle: "life is a factor of education" (Pestalozzi, 1947: p. 49). ${ }^{8}$ Bearing this assertion in mind, a fundamental element appears in this assertion made by the Swiss pedagogue: a child's education is based on nature (life) and, concurrently, must be an education for life.

Therefore, Pestalozzi claims that the foundation of both the method and the knowledge that the child will obtain, as well as the education to be offered, is "sensitive intuition" that is performed by the sensitive perception that the child will have, of concrete, empirical things.

The child has a special way of learning and communicating with the world; that is why it is the responsibility of educators, during the development of the pedagogical actions of teaching/learning, to make use of a method that requires "didactic-pedagogic" means fit for the child's reality. Every educational action is performed in the sense of leading "the child to learn to know himself/herself, that is, to learn to feel, observe, to know" (Pestalozzi, 2008: p. 150-151) and to become autonomous or independent. Pestalozzi explains:

The fate of the child is to become independent in all fields, by means through which his/her strengths are developed. He/she must necessarily receive care that is the root of his/her entire education, but that contains the seed of independence that will lead him/her-that must lead him/her-to free himself/herself of it (Pestalozzi, 2008: p. 116-117). ${ }^{10}$

Pestalozzi is even more emphatic in his view on childhood education when he explains that the pedagogical activity of the educator is performed and achieved

"'Du pont de vue intellectuel l'idée de formation élémentaire vient également à l'appui du príncipe pédagogique: 'la vie est un facteur d'éducation".

"“l'enfant à apprendre à se connaître lui-même, c'est-à-dire qu'il apprend à sentir, observer, connaître".

${ }^{10}$ le destin de l'enfant est de se rendre indépendant, dans tous les domaines, des moyens grâce auxquels se forces se sont développées. Il doit nécessairement recevoir des soins qui sont les racines de toute son éducation, mais que contiennent le germe de l'indépendance qui le conduira-qui doit le conduire-à s'en détacher. 
when he/she manages to make the child begin

Developing the forces and strengths in himself/herself that can make him/her no longer require the help of others. He/she is now ready to move forward at a steady pace following the path to perfection and to complete his/her education on his/her own. Had it not been this way, my home would not exist and my initiative would have failed (Pestalozzi, 2008: p. 87). ${ }^{11}$

However, the Swiss pedagogue, consistent with his worldview, defends the idea that the first steps of a child's education must be conducted within the context in which the child lives. Therefore, "instructing a child...must be done according to the child's external situation, the context in which he/she lives, considering the totality of his/her truth" (Pestalozzi, 2009: p. 39). ${ }^{12}$ By proceeding in this way, Pestalozzi wanted to teach man to forge himself through his own work ("as work of myself the world becomes world for me") (Pestalozzi, 2012: p. 226) because "through my own work, the world becomes meaningful for me" (Pestalozzi, 1994: p. 154, 161).

\section{Strategies of the Way-Method-For Achieving Objectives}

To Pestalozzi, the first foundation of all human knowledge is "sensitive impression, learned and fixed through attention, precisely expressed by language and made noble by its purpose" (Pestalozzi, 2011: p. 36), ${ }^{13}$ and its

Raw material is provided by sensitive impressions, particularly those of sight; these sensations that attract through novelty stir great interest in the child and indelibly mark him/her. This sensory representation of objects as they appear in nature may be called natural sensitive perception or intuition; for the school, it is empirical perception (Pestalozzi, 2011: p. 37). ${ }^{14}$

Therefore, it is not possible to propose "anything distant, anything strange to the child's conscience" (Pestalozzi, 2009: p. 29), ${ }^{15}$ since there is "a natural bond that must be established between the knowledge of words and of letters" (Pestalozzi, 2013: p. 35) ${ }^{16}$ It is precisely due to this natural "bond" that child literacy in

\footnotetext{
${ }^{11}$ développer en elle-même des forces et des moyens tels qu'elle peut se passer désormais de l'aide et de l'assistance des autres. Elle est alors en mesure de s'avancer d'un pas sûr dans la voie du perfectionnement et d'achever par elle-même sa formation. S'il n'en était ainsi, ma maison n'existerait pas et mon enterprise aurait échoué.

${ }^{12}$ l'instruction de l'enfant.doit être en accord avec la situation extérieure de l'enfant, avec le contexte dans lequel il vit, pris dans toute sa vérité.

13“le premier fondement de tout savoir humain est l'impression sensible, saisie et fixée par l'attention, précisée para la langue et ennoblie par la finalité".

${ }^{14}$ Matière première est fournie par les impressions sensibles, et tout particulièrement para celle de la vue, ces sensations qui ont l'attrait de la nouveauté, suscitent un grand intérêt chez l'enfant; elles le marquent de manière indélibile. On peut appeler cette représentation sensorielle des objets tels qu'ils se presentment dans la nature perception ou intuition sensible naturelle; pour l'école il s'agit de la perception empirique.

15“à sa conscience-de l'enfant-rien de lointain, rien d'étranger".

${ }^{16}$ Lien naturel qui doit s'établir entre la connaissance du monde réel et la connaissance des mots et des lettres.
} 
children's elementary education is developed based on the "connections" created between the sight of things in nature, objects, the signs that represent them, images, and the words that express them. This is why the course of children's education (bildung) goes from the thing, the object, the image of the object, and information about the thing, to the word that the child learns to write and communicate; this enables the child to learn to name things, or to master them through the word (Pestalozzi, 2013: p. 92, 100, 146). This constitutes a process involving "knowing and thinking, naming, and acting" (connaître et penser, nommer et agir)" (Pestalozzi, 2013: p. 163).

In fact, Pestalozzi, consistent with his worldview and with his vision for human education (bildung), intended to awaken in children and in human beings the ability to think for themselves, to dare to think, and dare to know: "Dare to know... Am I allowed to wish that men speak these terms whose words will have more importance than mine" (Pestalozzi, 1947: p. 304-305). ${ }^{17}$ Therefore, "the dare to know" by Immanuel Kant, is employed by Pestalozzi to justify his Method, which must encourage the child (the man) to discover his/her "wisdom" (as did Rousseau's Emilio and Sofia), forge himself/herself, and pronounce her/ his word.

Pestalozzi maintains the importance of "touch" (toucher) in relation to the objects, as then the child can "feel" them concretely and make connections between the words; he also believes that the image of the objects placed alongside the words helps the child to learn to read and write, following Comenius' recommendations. As Pestalozzi himself explains:

Yet, the circle of objects that surround man is limited; and Comenius ... felt the need to resort to images, thus creating his world through painting ... To the child, the images represent not only what he/she could not see in the objects around him/her, but also what he/she could see every day in nature itself. (Pestalozzi, 2009: p. 178) 18 $^{18}$

Therefore, the images transmit true "sensitive impressions" to children, i.e., they are "imprinted," through the sight of them and the words that express them, with their own meaning, since the images represent and need to represent things that relate to the child's world (Song fo the swan: Chant du cygne, 1947, p. 130). As long as the images (pictures) of things are also artistic expressions, they contribute to developing the child's creative ability (Song of the swan: Chant du cygne, 1947, p. 100 and 102) and to an "education through art and for the art of creating". (Pestalozzi, 2011: p. 45)

Another important element that is prominent among the methodological "instruments" proposed and used by Pestalozzi is the progressive teaching and

\footnotetext{
17“Aude sapere, incipe ... Il m'est permis de souhaiter que des hommes pronnoncent ces mots dont la parole aura plus d'importance et de poids que la mienne".

${ }^{18}$ Mais le cercle des objets qui entourent l'homme est borné; et Coménius ... sentit besoin de recourir aux images et créa son monde péint... Des images représetent à l'enfant non seulement ce qu'il ne pouvait pas voir dans les objets qui l'entouraient, mais aussi ce qu'il pouvait voir chaque jour en réalité dans la nature même.
} 
learning process that, in his view, must be gradual, respecting the child's age and the development of their ability to understand what Piaget would call in the twentieth century "cognitive development" according to age (Psychology of the child: Psychologie de l'enfant. Paris: Presses Universitaires de France, 1966; The birth of intelligence in children: La naissance de l'intelligence chez l'enfant. Neuchâtel: Délachaux et Niestlé, 1936).

Pestalozzi's dream was to concern himself with education, the poor, the unhappy, he believed that educating the poor, the "wretched of the earth," was difficult not because they are poor, but because

We do not make enough means available to be able to educate them so that they can beneficially use the strengths and abilities that their situations desperately require...i.e., means that can encourage their thinking and creativity (Pestalozzi, 2009: p. 224, 225). ${ }^{19}$

Being aware of the fact that "education is the road to salvation for the poor," he sought to fulfill his life-long dream by founding a school for educating the poor. This opened in Clendy in 1818 but, unfortunately, it did not prosper, even after it was converted into an annex or the Pestalozzi Institute in Yverdon. This school was intended for poor children and for training teachers who would work in rural areas, teachers whom Pestalozzi believed he could train in no more than three months (Pestalozzi, 2009: p. 234).

In his writings, Pestalozzi sought to clarify what the relationship between the educator and the educated would be. In his view, the educator, in performing pedagogical practice, must conduct "a dynamic unity of faith, love, and truth" (Song of the swan: Chant du cygne, Pestalozzi, 1947: p. 145, 152). ${ }^{20}$ That means that the educator cannot settle for superficial knowledge of the subject; it is essential for the educator to master it. Yet, this does not make him/her a gatekeeper of knowledge-proud, yet humble in the performance of the "mission." He is a "true" defender of the truth. In his practice, the educator leads the child to "notice things and knowledge itself as a live and organic whole whose elements overlap harmoniously with each other" (Pestalozzi, 2008: p. 151). ${ }^{21}$ Bearing this in mind, the educator "cannot be a tool, an inanimate distributor of a dead substance, similar to a machine, but must put himself/herself in the child's shoes" (Pestalozzi, 2008: p. 151). ${ }^{22}$ This requires the educator to assume an energetic stance and, concurrently, give lots of love-not love as "theory, but rather as love in action" (théorie, mais l'amour en acte) (Pestalozzi, 2009: p. 27), since "the person who does not love people is not worthy of them" (Pestalozzi, 2008: p. 61). ${ }^{23}$

\footnotetext{
19“'nous n'avons pas assez mis à disposition les moyens aptes à les former à une utilisation bénéfique des forces et capaités dont $\mathrm{Il}$ a un urgent besoin dans sa situation...c'est-à-dire, les moyens aptes à stimuler leur réflexion et leur criativité".

${ }^{20}$ une unité dynamique de la foi, de l'amour et de la vérité.

${ }^{21}$ "percevoir les choses et la connaissance elle-même comme un tout vivant et organique, dont les éléments s'imbriquent harmonieusement".

22“"ne peut pas être un pur outil, distributeur inanimé d'une matière morte, semblable à une machine, mais Il doit se placer du point du vue de l'enfant".

${ }^{23}$ car celui qui n'aime pas le peuple n'est digne de lui.
} 


\section{The Truth as a Purpose of the Pestalozzi Method and Mathematics as a Methodology}

Pestalozzi attributes the purpose of leading child and man to the truth of his teaching/learning Method by claiming that all of the Method's didactic-pedagogic actions lead to a sole possible objective, namely, the truth. According to him, these actions:

...lead to a sole possible target: the truth...it is thus that they lead to nothing other than approaching the truth, do not lead to anything but the truth, are not interested in anything but the truth. They cannot offer anything else, both due to their nature as well as due to their form; they cannot lead to anything more than the truth, nor interest anything other than the truth (Pestalozzi, 2008: p. 19). ${ }^{24}$

By way of conclusion, he said that "the only end of my teaching and of my Method is the truth. I wholeheartedly search for it" (2009, III, 154). This statement, as we have seen, can still be found on pages 150 and 170 of volume III of the Writings on the Method (Ecrits sur la Méthode), as mentioned above. I believe that searching for the truth as a purpose for the Method is related to, firstly, the fact that Pestalozzi, as a Christian and pietist, had the Gospel according to John (chapter 4, verse 16) in mind; specifically, the passage where the evangelist reproduces the statement by Jesus Christ that he is "the Way, the Truth, and the Life." Thus, the Method would be the path that would lead one to the truth and to life. Secondly, we can attribute the intransigent search for the truth with Pestalozzi's tenacity in valuing accuracy, numbers, mathematics, and figures with exact shapes, since, according to Pestalozzi, "every truth aims at certainty. Certainty is necessary; but we approach the truth and move in its direction, but what is arbitrary is erased; the greatest perfection of understanding is infallibility" (Pestalozzi, 2011: p. 58, 59). ${ }^{25}$ Hence, the "elementary number and form of exercises lead not only to recognizing, but also to discovering the truth" (Pestalozzi, 2009: p. 174). This is how Pestalozzi can conclude that his Method "is not the teaching of truths, but rather, the teaching about truth, since it guided me to the certainty of my judgment" (Pestalozzi, 2013: p. 158) ${ }^{26}$. For to him truth is mistaken for accuracy, and mathematics reflects precisely the exact.

\section{Conclusion}

Overall, according to the numbers and the forms,

\footnotetext{
${ }^{24} \ldots$ conduisent à un seul but possible: la vérité...c'est ainsi qu'elle parvient à n’approcher que de la vérité, à ne conduire qu'à la vérité, à n'intéresser qu'à la vérité... Elle ne peut donner rien d'autre, tant à cause de sa nature qu'à cause de sa forme, elle ne peut conduire à rien d'autre ni intéresser à rien d'autre.

${ }^{25}$ “toute vérité vise la certitude. La certitude est nécessaire; plus nous nous rapprochons de la vérité et avançons vers elle, plus l'arbitraire s'efface; la plus haute perfection de l'entendement est l'infaillibilité".

${ }^{26}$ n'est pas l'enseignement des vérités, mais elle est l'enseignement de la vérité, car il me conduit à la certude de mon jugement.
} 
"My method does nothing other than reproducing the simple course of nature. Therefore, following the path of nature in the development of the human genus, my method, due to the effect it has, and based on an intuitive vision it produces, forms in the mind of the child's capacity, beginning with observations of squares and rectangles and their divisions, to become aware, in their reality, of extremely complicated fractions and...become aware of the surface of a triangle, etc." (Pestalozzi, 2008: p. 20) ${ }^{27}$

Therefore, from the observation of the forms that nature presents and of the reproduction of objects found in nature, the child learns to write, to use numbers, reason, and the truth, and to read words as well as discover the world and its expressions. Pestalozzi explains his manner of seeing and working for the child's education and learning based on sensitive perception (i.e., induction):

"Every sensitive perception deeply imprinted in the human mind triggers a series of secondary notions that come more or less close to this perception...thus bringing together objects whose essence is the same; your understanding of the inner truth of these objects will be expanded, sharpened, and strengthened" (Pestalozzi, 2013: p. 86). ${ }^{28}$

Further on, he says:

"Yet if the form bears in itself, successively, and in various ways, the seed of error and illusion, the numbers do not... Only the number carries the infallible results. And, if the art of measuring demands the same priority, it might not intend this other than for the purpose of its alliance with the art of calculation and the help that it receives: it is infallible because it calculates" (Pestalozzi, 2013: p. 131). ${ }^{29}$

That is, when he conducts an entire reflection about arithmetic: the numbers are infallible; arithmetic is based on them, and this leads to accurate results. As long as they are accurate, they are true. Therefore, he believes that by using geometry, numbers, calculation, arithmetic, and mathematics, his Method leads to the purpose of the educational action: the truth: "I brought together sensitive intuition, reason, the sensitive mechanism and the purely intellectual action and, when finishing in the midst of this method with the confusing chaos of the many individual truths, I brought back teaching about the truth" (Pestalozzi, 2013: p.

\footnotetext{
${ }^{27} \mathrm{Ma}$ méthode ne fait donc rien d'autre que de reproduire le simple cours de la nature. Donc en suivant strictement la voie de la nature dans le développement du genre humain, ma méthode, grâce aux effets qu'elle produit ayant pour base une vision intuitive forme dans le sprit de l'enfant la capacité en partant des observations des carrés et des retangles avec leurs divisions, de prendre conscience, dans sa vérité, de fractions extrémement compliquées e... prendre conscience de la superficie du triangle, etc.

${ }^{28} \AA$ ̀ chaque perception sensible profondément imprimée dans l'esprit humain et rendu ineffaçable, s'enchaîne très une série de notions secundaires plus ou moins provhes de cette perception...en réunissant ensemble des obejts dont l'essence est la même, ta connaissance de la vérité intérieure de ces objets s'entrouvera profondément élargie, aiguisée et affermie.

${ }^{29}$ et si la forme porte en soi, bien souvent et de bien des manières, le germe de l'erreur et de l'illusion, le nombre jamais, et si l'art de mesurer revendique le même privilège, il ne peut pretendre qu'une raison de son alliance avec l'art du calcul et du secours qu'il em reçoit. Il est infaillible parce qu'il calcule.
} 
158). ${ }^{30}$

Due to the emphasis on forms, numbers, geometry, and mathematics as paths to the truth, people said that he wanted to "mechanize education." Nothing could be further from the truth, Pestalozzi believed: "I, like Rousseau, simply want to give the child himself/herself back again and lead him/her through teaching to a learning that follows the process of nature" (Pestalozzi, 2013: p. 36, 37). ${ }^{31}$

\section{References}

Pestalozzi, J. H. (1947). The Song of the Swang Followed by My Destinies (Le chant du cygnesuivi des mesdestinées). Boudry-Neuchâtel: Editions de la Baconnière.

Pestalozzi, J. H. (1985). Letters from Stans (Lettres de Stans). Uverdon-les-Bains: Ed. CDRP.

Pestalozzi, J. H. (1994). My Research on the Progress of Nature in the Evolution of Mankind (Mes recherches sur la marche de la nature dans l'évolution du genre humain. Lausanne: Ed. Payot.

Pestalozzi, J. H. (2007). Yes or Not? Considerations on the Political Humour of European Humanity in the Upper and Lower Classes by a Free Man (Oui ou non? Considérations sur l'humeur politique de l'humanité européenne dans les hautes et basses classes par un homme libre). Lausanne: LEP Éditions Loisirs et Pédagogie SA.

Pestalozzi, J. H. (2008). Writings on the Method I(Écrits sur la Méthode I). Lausanne: LEP Éditions Loisirs et Pédagogie SA.

Pestalozzi, J. H. (2009). Writings on the Method III (Écrits sur la Méthode, III). Le Mont-sur-Lausanne: Ed. Loisirs et Pédagogie S/A.

Pestalozzi, J. H. (2011). Writings on the Method IV (Écrits sur la Méthode IV). Le Mont-sur-Lausanne: Ed. Loisirs et Pédagogie S/A.

Pestalozzi, J. H. (2012). To the Innocence, the Gravity and the Nobility of My Time and My Country (À l'Innocence, à la gravité et à la noblesse de mon époque et de ma patrie). Lausanne: LEP Éditions Loisirs et Pédagogie SA.

Pestalozzi, J. H. (2013). Writings on the Method V(Écrits de la Méthode V). Le Mont-sur-Lausanne: ed. Loisirs et Pédagogie S/A.

Plutarch. (1927). Moralia (Volume 1). Cambridge, MA: Loeb Classical Library, Harvard University Press.

Snyders. G. (1988). Reflexions on Joy in School (A alegria na escola). São Paulo: Ed. Manole.

Soëtard, G. (1985). Introduction (Introduction). In J. H. Pestalozzi, Letters from Stans (Lettres de Stans). Uverdon-les-Bains: Ed. CDRP.

Soëtard, G. (1994). Commentary (Commentaire). In J. H Pestalozzi, My research on the progress of nature in the evolution of mankind (Mes recherches sur la marche de la nature dans l'évolution du genre humain. Lausanne: Éd. Payot.

Soëtard, M. (1982). Pestalozzi or the Birth of the Educator (Pestalozzi ou la naissance de l'éducateur). Berne, Francfort, Las Vegas: Peter Lang.

Thröler, D. (2008). Preface (Préface). In J. H. Pestalozzi (Ed.), Writings on the Method I (Écrits de la Méthode I). Lausanne: LEP Editions Loisirs et Pédagogie S/A.

${ }^{30}$ 'ai mis en harmonie l'intuition sensible et le jugement, le mécanisme sensible et la démarche purement intelelectuelle, et qu'em mettant fin, par cette méthode, au chaós confus de la multitude des vérités particulières, j’ai ramené l'enseignement à la vérité.

${ }^{31}$ Méchanizer l'éducation. “c'est pas vraie. Je ne veux que, comme Rousseau, rendre l'enfant à lui même, et l'amener par l'enseignement vers un apprentissage qui suit le processus de la nature. 
Submit or recommend next manuscript to SCIRP and we will provide best service for you:

Accepting pre-submission inquiries through Email, Facebook, LinkedIn, Twitter, etc. A wide selection of journals (inclusive of 9 subjects, more than 200 journals)

Providing 24-hour high-quality service

User-friendly online submission system

Fair and swift peer-review system

Efficient typesetting and proofreading procedure

Display of the result of downloads and visits, as well as the number of cited articles Maximum dissemination of your research work

Submit your manuscript at: http://papersubmission.scirp.org/

Or contact ce@scirp.org 